
\title{
28 Research Square \\ Culture of IMR90 Cells in Advanced MEM with Reduced Serum
}

\author{
Nicholas M. Mallek
}

University of North Carolina at Chapel Hill

Shaun D. McCullough ( $\triangle$ mccullough.shaun@epa.gov)

US Environmental Protection Agency https://orcid.org/0000-0001-6660-346X

\section{Method Article}

Keywords: IMR90, cell culture, reduced serum, Advanced MEM

Posted Date: November 3rd, 2021

DOl: https://doi.org/10.21203/rs.3.pex-1673/v1

License: (c) (i) This work is licensed under a Creative Commons Attribution 4.0 International License. Read Full License 


\section{Abstract}

NOTE: Methods document and worksheet versions of this method are attached as PDFs.

\section{SCOPE OF APPLICATION (LIMITATIONS)}

This method describes the thawing, culturing, and cryopreservation of the human lung fibroblast cell line IMR90 in Advanced MEM-based growth medium.

Disclaimer: The contents of this article have been reviewed by the US Environmental Protection Agency and approved for publication and do not necessarily represent Agency policy. Mention of trade names or commercial products does not constitute endorsement or recommendations for use.

\section{Introduction}

CAUTIONARY NOTES OR SPECIAL CONSIDERATIONS IMR90 cells are not known to be hazardous; however, they were derived from human samples and should be handled under BSL-2 precautions. Researchers should wear appropriate personal protective equipment during the completion of this protocol. A face shield should be worn while handling liquid nitrogen and cell vials that have been recently removed from liquid nitrogen storage as they may explode unexpectedly. Parental stocks of IMR90-ATCC cells were obtained from ATCC at passage 10 and frozen at both passage 13 (on $8 / 28 / 2017$ ) and passage 14 (on 8/31/2017). Since that time, we have started tracking cell growth in population doublings to obtain a more accurate representation of relative cell age. Thus, upon thawing of either passage 13/14 cells they are labeled with an "adjusted population doubling" (APD) of 0 . Thereafter, their growth will be recorded by the addition of the calculated number of population doublings per passage. APD values for IMR90s will often increase by 2.0-2.5 per passage early in their lifespan and decrease to between 1.5-2.0 over time in culture. When the APD is regularly below 1.3 , which typically takes about 12 passages according to the method described below, a new set of cells should be thawed. Bicarbonate buffered solutions used for cell culture, such as growth medium and DPBS, should be "regassed" after each usage to facilitate the maintenance of proper $\mathrm{pH}$. This can be accomplished by placing bottles in a tissue culture incubator for 15-30 minutes with the cap loosened, but still on the neck of the bottle, prior to closing/tightening the cap and storing at $4{ }^{\circ} \mathrm{C}$ until the next usage. Each user should have their own bottles of DPBS and growth medium to avoid cross contamination of cultures. Further, specific sets of growth medium, DPBS, and trypsin should be used for each cell line/type being maintained by each user.

\section{Reagents}




\section{Reagents}

Advanced Minimum Essential Medium (AMEM, Gibco \#12492-013)

GlutaMAX (Gibco \#35050-061)

Fetal bovine serum (Gibco \#16000-044)

100X penicillin/streptomycin solution (Gibco \#15140-122)

Dulbecco's phosphate buffered saline (DPBS, 1X, Gibco \#14190-144)

0.25\% Trypsin-EDTA (Gibco \#25200-056)

Dimethylsulfoxide (DMSO, Sigma \#D8418)

Isopropanol (Sigma \#19516)

Trypan Blue solution (0.4\%, Sigma \#T8154)

\section{Equipment}

\section{Equipment/Supplies}

- Biosafety cabinet

- Humidified tissue culture incubator at $37^{\circ} \mathrm{C}$ with $5 \% \mathrm{CO}_{2}$ at ambient $\mathrm{O}_{2}$

- Water bath at $37^{\circ} \mathrm{C}$

- Collagen coated tissue culture dishes

- 10 and $15 \mathrm{~cm}$ dishes (TPP \#93100 and 93150, respectively, coated according to McNabb and McCullough (2019))

- Pipetaid

- Serological pipettes (sterile, individually packaged)

- $50 \mathrm{~mL}$ conical tubes

- Sterile $150 \mathrm{~mL}$ and $250 \mathrm{~mL}$ bottles (Corning \#431175 and 430281, respectively)

- Tabletop centrifuge with swinging bucket rotor

Eppendorf tubes (autoclaved; USA Scientific \#1615-5500) 
- $\quad$ Pipettes

- Filter tips (sterile, low retention)

Hemocytometer

Syringe filter with $0.2 \mu \mathrm{m}$ pore (Millipore \#SLGP033RB)

“Mr. Frosty” cell freezing container (Nalgene \#5100-0001)

Long-term cell storage container with liquid nitrogen

\section{Procedure}

\section{PROCEDURE}

\section{Prepare Growth Medium}

1. Remove $20 \mathrm{~mL}$ a new bottle of Advanced MEM (AMEM) basal medium and discard.

2. Add the following to the remaining volume of AMEM in the bottle:

a. $10 \mathrm{~mL}$ of fetal bovine serum (FBS).

b. $10 \mathrm{~mL}$ of GlutaMAX.

c. Add $1 \mathrm{~mL}$ of $100 \mathrm{X}$ penicillin/streptomycin.

3. Mix thoroughly and label with the date and additives.

\section{Collagen Coating of Tissue Culture Plates}

IMR90 cells should be grown on dishes/plates/inserts that have been coated with $50 \mathrm{mg} / \mathrm{mL}$ bovine collagen I solution, as described in McNabb and McCullough (2019).

\section{Thawing Cryopreserved Cells}


1. Warm growth medium to $37^{\circ} \mathrm{C}$ and prepare materials prior to obtaining a vial of cells from cryostorage.

2. Remove vial from liquid nitrogen (wearing eye protection) and thaw in $37^{\circ} \mathrm{C}$ water bath $(1-2 \mathrm{~min})$.

a. It is important that cells are thawed quickly to reduce the duration of exposure to the high concentration of DMSO in the freezing medium, which will negatively impact cell viability.

3. Add $24 \mathrm{~mL}$ of growth medium to a $50 \mathrm{~mL}$ conical tube then transfer the thawed cells from the cryovial into the growth medium using a P1000 pipette and gently mix by inverting 10 times.

NOTE: do not vortex

4. Pellet cells via centrifugation at $1,000 \times g$ for 4 minutes at room temperature in centrifuge with a swinging bucket rotor.

5. Carefully aspirate the supernatant.

6. Gently resuspend the cells in $12 \mathrm{~mL}$ of pre-warmed growth medium, add $13 \mathrm{~mL}$ of additional growth medium, and transfer into a collagen-coated $15 \mathrm{~cm}$ dish. Distribute cell suspension on the dish through a combination of gentle rocking and swirling of the dish for approximately 15 seconds.

7. Place in a tissue culture incubator overnight.

8. Check cells the following day for attachment to the dish. Aspirate and replace medium.

a. NOTE: Use 10 and $25 \mathrm{~mL}$ of medium for 10 and $15 \mathrm{~cm}$ plates, respectively.

b. NOTE: It is preferable to subculture thawed cells for at least three passages before using in experiments. 


\section{$\underline{\text { Sub-Culturing_Cells }}$}

Cells should be split three days after being plated at either $4.0 \times 10^{4}$ cells $/ \mathrm{mL}$

NOTE: Lower APD IMR90 cells grow very quickly and should be plated at $3.5 \times 10^{4} \mathrm{cells} / \mathrm{mL}$ to start and then adjusted up to $4.0 \times 10^{4}$ cells/mL accordingly as their growth rate declines over time in culture.

1. Pre-warm growth medium and DPBS in a $37^{\circ} \mathrm{C}$ water bath and a trypsin aliquot at room temperature for approximately 30 minutes.

2. Aspirate the growth medium from plates to be passaged.

3. Rinse cells with pre-warmed DPBS and swirl gently for approximately five seconds.

a. $20 \mathrm{~mL}$ for $15 \mathrm{~cm}$ dishes

b. $10 \mathrm{~mL}$ for $10 \mathrm{~cm}$ dishes

4. Aspirate the DPBS wash.

5. Add trypsin and rotate gently to distribute evenly across the plate.

a. $1.5 \mathrm{~mL}$ (5 $\mathrm{mL}$ pipet) for $15 \mathrm{~cm}$ dish

b. $750 \mu \mathrm{L}$ (P1000 pipette) for $10 \mathrm{~cm}$ dish

6. Place in tissue culture incubator for 4 minutes, making sure not to stack dishes on top of each other. Following incubation, use the palm of your hand to gently tap the side of the dish to facilitate detachment. If cells are still attached, incubate for another 2 minutes. Incubate and tap dish until $>95 \%$ of the cells are detached. Check detachment with microscope.

a. NOTE: the duration of trypsinization may need to be optimized for each lot of trypsin. 
7. Add $12 \mathrm{~mL}$ growth medium, gently wash the surface of the dish with a pipette, and triturate once to break up any large cell clumps. Transfer the cell suspension to a $50 \mathrm{~mL}$ conical tube.

8. Wash the dish with an additional $12 \mathrm{~mL}$ of growth medium, collect, triturate, and add to the cell suspension from Step \#7.

9. Pellet cells at $1,000 \times g$ for 4 minutes at room temperature in centrifuge with a swinging bucket rotor.

10. Aspirate the supernatant and resuspend the cell pellet in $12 \mathrm{~mL}$ of growth medium. Triturate at least four times to thoroughly break up the majority of clumped cells. Add additional growth medium to dilute the cell suspension if desired. Typically, growth medium is added such that there is a total volume of 12 $\mathrm{mL}$ per $2-315 \mathrm{~cm}$ plates collected. Mix thoroughly by inverting the tube 10 times.

11. Prepare a 1:1 dilution of the cell suspension in trypan blue ( $50 \mu \mathrm{L}$ trypan blue $+50 \mu \mathrm{L}$ cell suspension) in an Eppendorf tube.

12. Count cells that exclude trypan blue (i.e., appear clear) on both sides of a hemocytometer (do not use an automated cell counter as these cells display variability in size and are not accurately quantified by automated methods).

a. NOTE: Blue staining of cells indicates a damaged membrane. Blue-stained cells are considered to be non-viable.

13. Calculate the cell concentration in the cell suspension.

14. Determine the new culture APD.

a. Calculate and record the number of cells obtained per plate during this passage.

b. Calculate the number of population doublings that occurred during the last passage (include the indicated values in the associated worksheet) and adding that number to the previous APD: 


\section{([(3.32(log(cells collected per plate)-log(cells plated per plate)) + previous APD ])}

15. Dilute cells to $4.0 \times 10^{4}$ cells $/ \mathrm{mL}$ in growth medium in a $50 \mathrm{~mL}$ tube (or larger sterile bottle based on needed volume) to the total volume that will be used for plating $(10 \mathrm{~mL}$ for each $10 \mathrm{~cm}$ plate and $25 \mathrm{~mL}$ for each $15 \mathrm{~cm}$ plate, making 2-5 $\mathrm{mL}$ extra).

16. Mix thoroughly by inverting 10 times and dispense the diluted cell suspension into each dish. Distribute cell suspension on the dish through a combination of gentle rocking and swirling of the dish for approximately 15 seconds.

17. Place in a tissue culture incubator. Cells will be ready to split three days after plating.

a. NOTE: Plating cells at a determined cell density will result in more predictable sub-culture and more reproducible performance in subsequent experimental assays.

18. Place bottles of growth medium and DPBS in $5 \% \mathrm{CO}_{2}$ incubator with lids partially unscrewed for 15 minutes to adjust $\mathrm{pH}$ before returning to $4^{\circ} \mathrm{C}$ for storage.

\section{Preparing cells for cryopreservation}

1. Prepare freezing medium.

a. $50 \%$ FBS, $40 \%$ growth medium, $10 \%$ DMSO.

b. Filter through a $0.2 \mu \mathrm{m}$ pore syringe filter into a $50 \mathrm{~mL}$ conical tube.

2. Follow sub-culturing protocol through Step \#10.

3. Determine the number of cells present and pellet cells at $1,000 \times g$ for 4 minutes at room temperature in centrifuge with a swinging bucket rotor. 
4. Carefully aspirate the supernatant and resuspend the cell pellet in freezing medium at a density of $1.25 \times 10^{6}$ cells $/ \mathrm{mL}$.

5. Mix cell suspension by gently inverting 10 times and dispense $1 \mathrm{~mL}$ aliquots into cryovials with a P1000 pipette.

6. Place cryovials in a Mr. Frosty freezing container (filled to indicated line with isopropyl alcohol) and place in a $-80^{\circ} \mathrm{C}$ freezer overnight.

a. The chamber regulates cooling rate at approximately $1^{\circ} \mathrm{C}$ per minute.

b. NOTE: Isopropanol should be changed after every three freezing cycles.

C. NOTE: Do not leave vials at $-80^{\circ} \mathrm{C}$ longer than overnight as it will impact viability after thawing.

7. Transfer the frozen vials in liquid nitrogen storage.

\section{References}

https://www.atcc.org/ /media/PDFs/Culture\%20Guides/AnimCellCulture_Guide.ashx

McNabb, N. and McCullough, S. (2019). Collagen Coating for Tissue Culture. Protoc Exch. https://doi.org/10.21203/rs.2.20355/v1.

\section{Supplementary Files}

This is a list of supplementary files associated with this preprint. Click to download.

- 2020WorksheetforCultureofIMR90CellsinAdvancedMEMwithReducedSerum.pdf

- 2020CultureofIMR90CellsinAMEMV1.pdf 